Resumo

\title{
Efeito agudo imediato das passagens na Pista de Treinamento em Circuito sobre a força muscular
}

Uriel Dias de Lima Arêas Bsci, Runer Marson PhD

Introdução: Embora haja estudos sobre o treinamento em circuito, a literatura apresenta-se carente em relação às pesquisas voltadas para a influência dos intervalos sobre a resposta neuromuscular.

Objetivo: Verificar o efeito agudo dos intervalos na valência força muscular na passagem da Pista de Treinamento em Circuito.

Métodos: Participaram do estudo sete alunos do Curso de Instrutor de Educação Física com média de 27,14 $( \pm 1,95)$ anos, estatura média de 175,14 $( \pm 5,26) \mathrm{cm}$ e massa corporal média de $73,84( \pm 6,14) \mathrm{kg}$, em condições de saúde plenas. A coleta de dados foi realizada ao término da passagem na PTC. Os voluntários executaram os testes de forças de tração lombar (TF-Lmb), tração escapular (TFEsc) e preensão manual (TF-Mnl) de forma randômica. Para os testes de força o voluntário executou três ações voluntárias máximas, com estímulos verbais, durante 4 segundos (s) com intervalo entre as ações de 15s. Todos foram orientados quanto aos posicionamentos e procedimentos na execução dos testes.

Resultados: Nos testes de força de preensão manual (FPM) encontraram-se valores médios de 36,17 \pm 6,42 kgf para condição inicial, 35,32 \pm 7,13 kgf para intervalo de 30s (T30), 34,15 \pm 5,93 kgf para intervalo de 45s (T45) e 33,03 \pm 5,84 kgf para intervalo de 60s (T60). Na força de tração lombar (FLmb) foram encontrados valores médios de 173,99 $\pm 21,57$ kgf para condição inicial, 178,06 $\pm 32,31$ kgf para intervalo de 30 segundos (T30), 168,14 $\pm 32,43 \mathrm{kgf}$ para intervalo de 45 segundos (T45) e 176,81 $\pm 30,69$ kgf para intervalo de 60 segundos (T60). Já nos testes de força de tração escapular (FEscp) encontraramse valores médios de 20,58 \pm 3,86 kgf para condição inicial, 19,89 $\pm 3,36 \mathrm{kgf}$ para intervalo de 30s (T30), 20,39 \pm 9,42 kgf para intervalo de 45s (T45) e 29,93 \pm 9,19 kgf para intervalo de 60s (T60).

Conclusão: Não houve modificações significativas na valência força muscular para as passagens na PTC nos intervalos de 30s, 45s e 60s nos testes de FPM e de FLmb. No teste de FEscp houve diferença estatisticamente significativa na valência força somente para passagem na PTC no intervalo de 60s. 